\title{
Analisis Ekspor Biji Pala Indonesia ke Tujuh Negara Uni Eropa Periode 2012-2019
}

\author{
(Analysis of Indonesian Nutmeg Export Volume to Seven European Union Countries in 2012-2019) \\ Amalia Susanti ${ }^{1 *}$, Lia Yuliana ${ }^{2}$ \\ ${ }^{1,2}$ Politeknik Statistika STIS \\ Jalan Otto Iskandardinata Nomor 64C Jakarta 13330 \\ E-mail: 211709538@stis.ac.id
}

\begin{abstract}
ABSTRAK
Uni Eropa merupakan pasar kedua terbesar bagi ekspor biji pala Indonesia selama periode 2012-2019 dengan rata-rata total nilai ekspor sebesar 44,46 juta US\$. Meski memiliki prospek yang baik, kegiatan ekspor biji pala Indonesia ke Uni Eropa sempat mengalami kendala yang berakibat pada menurunnya volume ekspor. Oleh karena itu, penelitian ini bertujuan untuk mengetahui daya saing serta faktor apa saja yang diduga berpengaruh terhadap volume ekspor biji pala Indonesia periode 2012-2019. Metode yang digunakan adalah analisis deskriptif menggunakan RCA dan EPD serta analisis inferensia menggunakan analisis regresi data panel. Hasil penelitian menunjukkan bahwa biji pala Indonesia telah memiliki keunggulan komparatif dengan posisi pasar falling star dan retreat. Kemudian, regulasi HC, laju produksi pala Indonesia, dan indeks daya saing (RCA) berpengaruh positif signifikan terhadap volume ekspor biji pala Indonesia. Sedangkan harga riil ekspor berpengaruh negatif signifikan.
\end{abstract}

Kata kunci: biji pala, daya saing, regulasi health certificate, regresi data panel

\begin{abstract}
The European Union is the second largest market for the export of Indonesian nutmeg in 2012-2019 with an average total export value of 44.46 million US \$. Despite having good prospects, Indonesian nutmeg export to the European Union had experienced obstacles that resulted in the decline in export volume. Therefore, this study aims to determine the competitiveness and factors that affect the volume of Indonesian nutmeg for the 2012-2019 period. The method used is descriptive analysis using RCA and EPD and inferential analysis using panel data regression analysis. The results of the study indicate that Indonesian nutmeg have a comparative advantage with the position of the market of Falling Star and Retreat. Then, HC regulation, Indonesian nutmeg production rate, and index RCA has a significant positive effect on the volume of Indonesian nutmeg exports. While the real price of exports has a significant negative effect.
\end{abstract}

Keywords: nutmeg, competitiveness, health certificate regulation, panel data regression

\section{PENDAHULUAN}

Berdasarkan data BPS, sub-sub sektor perkebunan memberikan kontribusi PDB terbesar selama periode 2012-2019 bagi sub sektor pertanian, peternakan, perburuan dan jasa pertanian sebesar 36,88-39 persen. Selain itu, sub-sub sektor perkebunan juga memberikan kontribusi dalam membangun perekonomian nasional, sumber devisa negara dari ekspor, meningkatkan penerimaan negara melalui cukai, pajak ekspor, dan sebagainya (Direktorat Jenderal Perkebunan, 2019). Salah satu komoditas perkebunan yang memiliki potensi besar dalam menghasilkan devisa negara melalui ekspor adalah pala.

Pala merupakan tanaman asli Indonesia yang berasal dari Maluku dan kepulauan Banda. Kualitas produk pala yang dihasilkan cenderung rendah. Hal ini karena produksi pala Indonesia sebagian besar dikelola oleh perkebunan rakyat yang masih melakukan penanganan pascapanen secara tradisional (Direktorat Jenderal Perkebunan, 2019). Berdasarkan data rata-rata produksi pala Indonesia selama periode 2012-2019, sentra produksi pala Indonesia terdapat di lima provinsi, yaitu Aceh, Sulawesi Utara, Maluku Utara, Papua Barat, dan Maluku dengan kontribusi masing-masing sebesar 20,36\%, 18,89\%, 18,28\%, 16,29\%, dan 13,57\% (Kementerian Pertanian, 2016; Direktorat Jenderal Perkebunan, 2019). Indonesia merupakan negara produsen pala terbesar bersama dengan India dan Guatemala dan menjadi salah satu pemasok kebutuhan pala terbesar dunia (Hafif, 2021).

Berdasarkan data UN Comtrade, jenis komoditas pala yang banyak diekspor oleh Indonesia adalah biji pala (HS 090810). Biji pala Indonesia banyak digemari oleh negara-negara di dunia, termasuk Uni Eropa. Hal ini ditunjukkan dengan Uni Eropa sebagai pasar ekspor biji pala Indonesia terbesar kedua setelah Vietnam selama periode 2012-2019 dengan rata-rata volume ekspor sebesar 2,85 ribu ton (UN Comtrade). Pasar yang 
besar ini menghasilkan devisa negara Indonesia dengan rata-rata total nilai sebesar 44,46 juta US\$. Namun, hasil yang baik ini tidak terlepas dari berbagai kendala, salah satunya ketatnya standar keamanan pangan yang diterapkan oleh Uni Eropa. Ketatnya standar tersebut berdampak pada penolakan komoditas biji pala Indonesia, yang secara umum disebabkan oleh kandungan aflatoksin pada biji pala Indonesia yang melebihi batas maksimal yang telah ditentukan sehingga memberikan dampak pada menurunnya volume ekspor serta harga jual komoditas biji pala Indonesia ((DG(SANTE), 2016); Dewi, 2016; Lawalata, 2019).

Regulasi keamanan pangan telah banyak digunakan, terutama oleh negara maju, untuk menekan impor (Atici, 2013). Selain digunakan sebagai trade barrier (hambatan perdagangan), semakin sadarnya akan dampak kesehatan yang dapat ditimbulkan dari mengkonsumsi bahan pangan yang mengandung aflatoksin tinggi, diduga turut memberikan dorongan untuk menetapkan regulasi keamanan pangan dengan standar yang ketat (Rosman, 2020). Pada tahun 2010, Uni Eropa mengeluarkan aturan mengenai batas maksimal aflatoksin yang terkandung dalam biji pala yang akan diekspor ke wilayah Uni Eropa. Hal ini diatur dalam Regulasi Uni Eropa No. 165, di mana batas maksimal untuk aflatoksin B1 sebesar $5 \mu \mathrm{g} / \mathrm{kg}$ dan aflatoksin total sebesar $10 \mu \mathrm{g} / \mathrm{kg}$. Kemudian diperketat kembali dengan Regulasi Uni Eropa No. 24 Tahun 2016 mengenai kewajiban menyertakan sertifikat keamanan dan kesehatan pangan (health certificate) bagi biji pala Indonesia yang akan diekspor ke Uni Eropa.

Mankiw (2003) dan Sukirno (2004) menjelaskan bahwa kegiatan ekspor suatu negara dapat dipengaruhi oleh beberapa faktor, di antaranya kebijakan pemerintah terkait perdagangan luar negeri, keadaan perekonomian konsumen di luar negeri, harga komoditas, kemampuan produksi suatu negara, kemampuan menghasilkan komoditas unggul, kurs, dan sebagainya. Namun penelitian ini membatasi faktor-faktor yang diduga mempengaruhi volume ekspor biji pala Indonesia ke Uni Eropa menjadi regulasi health certificate, PDB riil per kapita negara tujuan, harga riil ekspor biji pala Indonesia, laju produksi pala Indonesia, serta daya saing ekspor biji pala Indonesia. Sedangkan untuk kurs tidak diikutkan dalam analisis. Hal ini atas dasar pertimbangan negara-negara Uni Eropa yang memiliki mata uang yang sama, yaitu Euro.

Penelitian yang dilakukan oleh Atici (2013) menemukan bahwa regulasi keamanan pangan dapat memiliki dua pengaruh terhadap volume ekspor komoditas suatu negara, yaitu positif atau negatif. Selain itu, semakin tinggi PDB riil per kapita negara tujuan ekspor dan produksi domestik akan meningkatkan volume ekspor. Kemudian penelitian yang dilakuakan oleh Maulana \& Kartiasih (2017) mengemukakan bahwa semakin tinggi PDB riil per kapita negara tujuan ekspor dan daya saing komoditas akan meningkatkan volume ekspor. Sedangkan semakin tinggi harga riil ekspor, volume ekspor akan semakin menurun. Soeharjoto (2016) menemukan bahwa daya saing yang diwakili oleh indeks RCA memiliki pengaruh positif terhadap volume ekspor.

Berdasarkan pemaparan di atas, penelitian ini dilakukan untuk mengetahui gambaran umum volume ekspor biji pala Indonesia serta daya saingnya di tujuh negara Uni Eropa periode 2012-2019, dan pengaruh diberlakukannya regulasi health certificate, PDB riil per kapita negara tujuan, harga riil ekspor biji pala Indonesia, laju produksi pala Indonesia, serta daya saing ekspor biji pala Indonesia terhadap volume ekspor biji pala Indonesia ke tujuh negara Uni Eropa periode 2012-2019.

\section{METODE}

\section{Landasan Teori}

\section{Perdagangan Luar Negeri}

Tambunan dalam Maulana \& Kartiasih (2017) menjelaskan bahwa perdagangan luar negeri merupakan kegiatan perdagangan antarnegara yang terdiri dari ekspor dan impor. Ekspor merupakan kegiatan penjualan atau pengiriman barang dari dalam negeri ke luar negeri. Sukirno (2004) mengemukakan bahwa perdagangan luar negeri memberikan keuntungan, di antaranya memperoleh barang yang tidak dapat diproduksi di dalam negeri, memperoleh keuntungan dari spesialisasi, memperluas industri-industri dalam negeri, serta menggunakan teknologi modern dan meningkatkan produktivitas.

Regulasi Health Certificate

Kegiatan ekspor suatu negara tidak dapat terlepas dari hambatan perdagangan. Regulasi health certificate merupakan salah satu jenis regulasi keamanan pangan yang banyak digunakan sebagai hambatan perdagangan dalam bentuk non tarif. Atici (2013) menjelaskan bahwa regulasi keamanan pangan memiliki tiga efek, yaitu efek penghambatan perdagangan, efek netral dan efek katalis. Efek penghambatan perdagangan terjadi akibat dampak negatif regulasi yang berujung pada menurunnya ekspor komoditas suatu negara. Sedangkan efek katalis terjadi ketika regulasi yang diberlakukan memaksa negara pengekspor untuk berinvestasi lebih banyak pada ekspor komoditas tertentu dan meningkatkan pangsa pasarnya. 


\section{PDB Riil per Kapita}

Mankiw (2003) menjelaskan bahwa PDB riil per kapita merupakan indikator yang baik untuk menggambarkan kesejahteraan ekonomi penduduk di suatu negara. Semakin tinggi nilai PDB riil per kapita suatu negara artinya semakin tinggi kesejahteraan ekonomi rata-rata penduduk suatu negara, begitu juga sebaliknya. Oleh karena itu, PDB riil per kapita dapat digunakan untuk melihat kemampuan atau daya beli suatu negara. Hal ini dapat meningkatkan permintaan penduduk di negara tersebut terhadap komoditas impor sehingga meningkatkan ekspor dari mitra dagangnya.

\section{Harga Riil Ekspor}

Harga riil merupakan harga suatu barang relatif terhadap ukuran agregat harga atau secara sederhana merupakan harga yang telah disesuaikan dengan inflasi (Pindyck \& Rubinfield, 2007). Ukuran agregat harga yang paling sering digunakan adalah indeks harga konsumen (IHK). Formula untuk menghitung harga riil suatu periode waktu menurut Pindyck \& Rubinfeld (2007), yaitu:

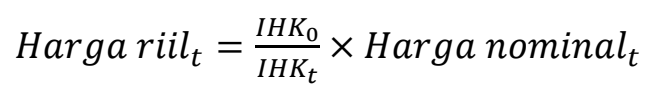

Keterangan:

$$
I H K_{0}: \text { Indeks harga konsumen pada tahun dasar }
$$

$I H K_{t}:$ Indeks harga konsumen pada tahun ke- $t$

Harga merupakan salah satu faktor yang dapat memengaruhi ekspor suatu komoditas (Mankiw, 2003). Hukum permintaan menyatakan bahwa peningkatan harga barang atau jasa akan menurunkan permintaan akan barang atau jasa tersebut, begitu juga sebaliknya. Oleh karena itu, ketika harga ekspor meningkat dapat menurunkan permintaan akan komoditas yang diekspor tersebut (Wiranthi \& Mubarok, 2017; Maulana \& Kartiasih, 2017; Sofjan, 2017).

Laju Produksi Pala

Produksi merupakan kegiatan menghasilkan atau menambah nilai suatu produk berupa barang atau jasa. Produksi merupakan salah satu faktor penting bagi kegiatan ekspor suatu negara. Kinerja produksi dapat dilihat dengan menggunakan pertumbuhan produksi yang dihitung menggunakan rumus sebagai berikut:

$$
\text { laju produksi } i_{t}=\frac{\text { produksi }_{t}-\text { produksi }_{t-1}}{\text { produks }_{t-1}} \times 100 \%
$$

Ketika produksi dalam negeri melimpah dan telah memenuhi kebutuhan dalam negeri, akan terjadi excess supply sehingga negara akan memperluas pasar ke luar negeri melalui ekspor (Sukirno, 2004). Oleh karena itu, ketika terjadi peningkatan produksi dalam negeri, volume ekspor suatu negara akan meningkat dari sisi penawaran (Atici, 2013; Khoironi \& Saskara, 2017; Hakiki \& Asnawi, 2019).

\section{Daya Saing}

Daya saing merupakan salah satu faktor yang dapat mempengaruhi ekspor. Kemampuan suatu negara dalam melakukan produksi serta inovasi dalam meningkatkan kualitas produk menjadi faktor penentu tingkat daya saing di perdagangan internasional (Soeharjoto, 2016). Beberapa indikator yang dapat digunakan untuk mengukur daya saing ekspor di antaranya adalah indeks revealed comparative advantage (RCA) dan export product dynamics (EPD).

\section{Cakupan Penelitian}

Penelitian ini menggunakan data panel dengan jumlah unit observasi sebanyak tujuh negara Uni Eropa, yaitu Belanda, Belgia, Inggris, Italia, Jerman, Prancis, dan Spanyol pada periode 2012-2019. Variabel dependen pada penelitian ini adalah volume ekspor biji pala Indonesia ke tujuh negara Uni Eropa. Sedangkan variabel independen meliputi dummy regulasi health certificate, PDB riil per kapita negara tujuan (ribu US\$), harga riil ekspor biji pala Indonesia di negara tujuan (US\$), laju produksi pala Indonesia (\%), dan indeks daya saing (RCA) biji pala Indonesia di negara tujuan.

\section{Metode Analisis}

Metode analisis yang digunakan adalah analisis deskriptif berupa analisis daya saing menggunakan metode revealed comparative advantage (RCA) serta analisis export product dynamics (EPD). Selain itu, dilakukan analisis inferensia untuk mengetahui pengaruh regulasi HC serta faktor lainnya terhadap volume 
ekspor biji pala Indonesia ke tujuh negara Uni Eropa periode 2012-2019. Jumlah observasi sebanyak 56 dengan unit observasi tujuh negara Uni Eropa pada periode 2012-2019.

\section{Revealed Comparative Advantage (RCA)}

Indeks RCA pertama kali diperkenalkan oleh Balassa pada tahun 1965 (Laursen, 2015). Balassa menyatakan bahwa keunggulan komparatif dapat dilihat melalui pola perdagangan, yaitu pangsa pasar ekspor yang tinggi. Apabila indeks RCA menunjukkan nilai yang lebih dari satu, negara memiliki keunggulan komparatif atau dapat dikatakan pangsa ekspor produk berada di atas rata-rata dunia. Formula untuk menghitung nilai indeks RCA adalah sebagai berikut.

$R C A=\frac{\frac{x_{i j}}{X_{j}}}{\frac{X_{i w}}{X_{w}}}$

Keterangan:

$X_{i j} \quad: \quad$ nilai ekspor komoditi komoditas i negara $\mathrm{j}$

$X_{j} \quad$ : nilai total ekspor negara $\mathrm{j}$

$X_{i w}:$ nilai ekspor komoditas i dunia

$X_{w} \quad$ : nilai total ekspor dunia

Export Product Dynamic (EPD)

Komoditas suatu negara dikatakan kompetitif ketika pangsa pasarnya berada dalam keadaan meningkat. Kemudian dikatakan dinamis dalam perdagangan dunia apabila pangsa pasarnya tumbuh lebih cepat dari ratarata untuk seluruh komoditas (Estherhuizen, 2006). Export product dynamic (EPD) merupakan indikator yang digunakan untuk menggambarkan posisi pertumbuhan pangsa pasar suatu negara pada perdagangan dunia. Formula untuk menghitung export product dynamics adalah sebagai berikut (Wiranthi \& Mubarok, 2017).

Pertumbuhan pangsa pasar ekspor (sumbu $\mathrm{x}$ ):

$\frac{\sum_{t=1}^{T}\left(\frac{X_{i j}}{X_{i w}}\right)_{t} \times 100 \%-\sum_{t=1}^{T}\left(\frac{X_{i j}}{X_{i w}}\right)_{t-1} \times 100 \%}{T}$

Pertumbuhan pangsa pasar produk (sumbu y):

$\frac{\sum_{t=1}^{T}\left(\frac{X_{j}}{X_{w}}\right)_{t} \times 100 \%-\sum_{t=1}^{T}\left(\frac{X_{j}}{X_{w}}\right)_{t-1} \times 100 \%}{T}$

Kombinasi hasil penghitungan antara pertumbuhan pangsa pasar ekspor dengan pertumbuhan pangsa pasar produk dapat terklasifikasikan menjadi empat kategori pada Tabel 1, yaitu raising star, lost opportunity, falling star, dan retreat.

Tabel 1. Matriks posisi pasar

\begin{tabular}{ccc}
\hline Pangsa pasar ekspor total $(\mathrm{Y})$ & \multicolumn{2}{c}{ Pangsa pasar ekspor komoditas (X) } \\
\cline { 2 - 3 } & Rising (Dynamic) $(+)$ & Falling (Stagnant) $(-)$ \\
\hline Rising (Competitive) $(+)$ & Rising star & Lost opportunity \\
Falling (non-competitive) $(-)$ & Falling star & Retreat \\
\hline
\end{tabular}

Sumber: Nabi \& Luthria, 2002

Analisis Regresi Data Panel

Berikut ini adalah tahapan analisis inferensia dengan menggunakan regresi data panel.

1. Melakukan pemodelan regresi data panel.

2. Memilih model terbaik antara common effect, fixed effect, atau random effect model.

3. Melakukan pengujian pada struktur varians-kovarians residual ketika model terbaik yang terpilih adalah common effect model atau fixed effect model. Pengujian pertama dilakukan untuk melihat apakah struktur varians-kovarians bersifat homoskedastis atau heteroskedastis menggunakan uji lagrange multiplier. Apabila terbukti bersifat heteroskedastis, pengujian dilanjutkan untuk melihat keberadaan cross-sectional correlation pada struktur varians-kovarians residual dengan menggunakan uji $\lambda_{L M}$. 
4. Memilih metode estimasi yang sesuai dengan hasil pengujian struktur varians-kovarians residual.

5. Melakukan uji asumsi klasik. Ketika metode estimasi yang terpilih adalah ordinary least square (OLS), asumsi yang harus terpenuhi adalah normalitas, homoskedastisitas, non-autokorelasi, dan non multikolinearitas.

6. Menguji keberartian model dengan koefisien determinasi Adjusted $R$-square, uji simultan menggunakan F-test, serta pengujian secara parsial menggunakan t-test.

7. Menginterpretasikan model yang diperoleh.

Berikut ini adalah model regresi data panel yang dibentuk untuk menganalisis faktor-faktor yang diduga mempengaruhi volume ekspor biji pala Indonesia ke tujuh negara Uni Eropa periode 2012-2019.

lnEkspor $_{i t}=\alpha+\beta_{1} D H C_{t}+\beta_{2} P D B_{i t}+\beta_{3}$ Harga $_{i t}+\beta_{4}$ Produksi $_{t}+\beta_{5} \operatorname{lnRCA_{it}}+w_{i t}$

dimana

$w_{i t}=\mu_{i}+u_{i t}$

Keterangan:

Ekspor $_{\text {it }} \quad$ : volume ekspor biji pala Indonesia ke negara i pada tahun $\mathrm{t}$

$D_{H} C_{t} \quad:$ dummy regulasi health certificate pada periode waktu $\mathrm{t}$

$P D B_{i t} \quad:$ PDB riil per kapita negara i pada tahun $\mathrm{t}$

Harga $_{i t}$ : harga riil ekspor biji pala Indonesia di negara i pada tahun $\mathrm{t}$

Produksi $_{t}$ : laju produksi pala Indonesia pada tahun $\mathrm{t}$

$R C A_{i t} \quad:$ indeks daya saing produk biji pala Indonesia di negara i pada tahun $\mathrm{t}$

$\alpha \quad:$ intersep

$\beta_{1}, \ldots, \beta_{5} \quad:$ koefisien regresi variabel independen

$w_{i t} \quad:$ error komposit individu ke-i pada periode ke-t

$\mu_{i} \quad:$ efek individu

$u_{i t} \quad:$ komponen error gabungan individu ke-i pada periode ke- $\mathrm{t}$

$i \quad: \quad$ Belanda, Belgia, Inggris, Italia, Jerman, Prancis, Spanyol

$t \quad:$ 2012, 2013, .., 2019

\section{Data dan Sumber Data}

Data yang digunakan merupakan data sekunder yang diperoleh dari tabel dinamis website resmi BPS yakni www.bps.go.id, UN comtrade, dan World Bank. Data beserta sumber data yang digunakan pada penelitian ini adalah sebagai berikut.

1. Data volume dan nilai ekspor biji pala Indonesia ke tujuh negara Uni Eropa dan dunia periode 2012-2019 berasal dari website UN Comtrade yakni https://comtrade.un.org/data/ memiliki satuan kilogram dan US\$.

2. Data PDB riil per kapita tujuh negara Uni Eropa periode 2012-2019 berasal dari website resmi World Bank yakni https://data.worldbank.org/indicator/NY.GDP.PCAP.KD memiliki satuan ribu US\$.

3. Data jumlah produksi pala Indonesia periode 2012-2019 berasal dari publikasi Kementerian Pertanian yaitu Outlook Pala 2020 memiliki satuan ton.

4. Data harga nominal ekspor biji pala Indonesia periode 2012-2019 berasal dari website UN Comtrade yakni https://comtrade.un.org/data/ memiliki satuan US\$/kilogram.

5. Data Indeks Harga Konsumen $(2010=100)$ dari tujuh negara tujuan ekspor di Uni Eropa periode 20122019 berasal dari website resmi World Bank yakni https://data.worldbank.org/indicator/FP.CPI.TOTL.

\section{HASIL DAN PEMBAHASAN}

\section{Gambaran Umum Volume dan Harga Riil Ekspor Biji Pala Indonesia ke Tujuh Negara Uni Eropa Periode 2012-2019}

Berdasarkan Gambar 1, volume ekspor biji pala Indonesia ke tujuh negara Uni Eropa cenderung berfluktuasi selama periode 2012-2019. Belanda merupakan negara yang paling banyak menyerap ekspor biji pala Indonesia dengan rata-rata sebesar 940,69 ton, diikuti oleh Jerman, Italia, Belgia, Spanyol, Prancis, dan Inggris dengan rata-rata masing-masing sebesar 733,45 ton; 485,47 ton; 212,23 ton; 155,82 ton; 145,47 ton; 101,14 ton. Ekspor biji pala Indonesia ke negara Belanda periode 2012-2019 merupakan yang terbesar 
dibandingkan keenam negara lainnya. Hal ini karena selain menjadi pasar yang potensial karena kepopulerannya, Belanda merupakan salah satu pasar re-ekspor terbesar bagi biji pala Indonesia.

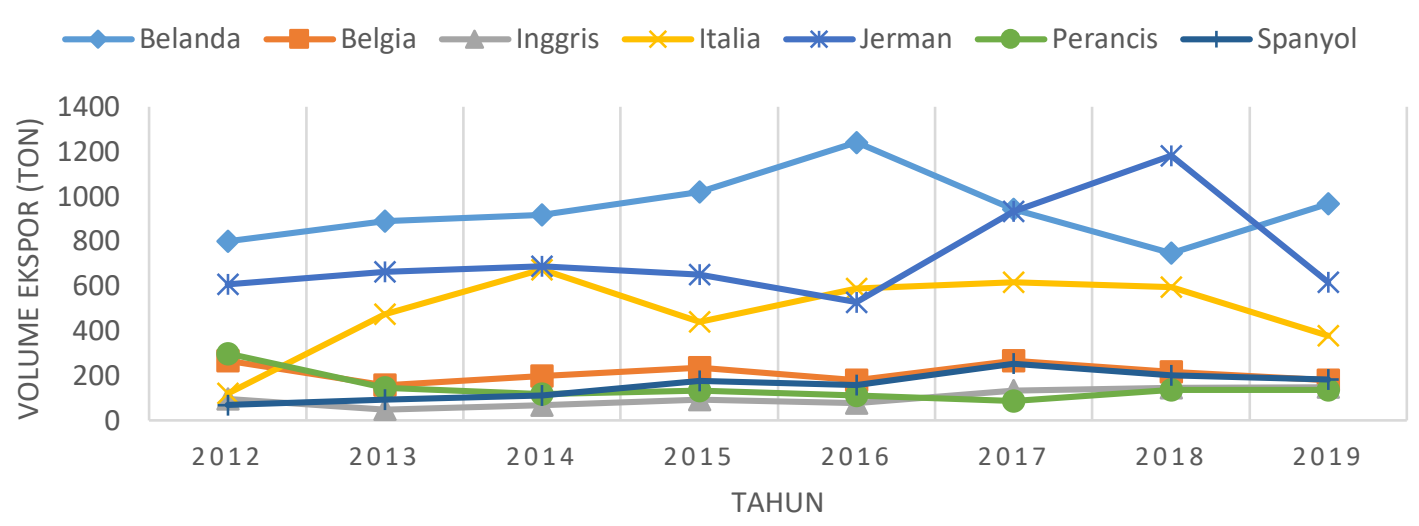

Sumber: UN Comtrade (diolah)

Gambar 1. Volume ekspor biji pala Indonesia ke negara Belanda, Belgia, Inggris, Italia, Jerman, Prancis, dan Spanyol periode 2012-2019

\section{Daya Saing Biji Pala Indonesia di Tujuh Negara Uni Eropa Periode 2012-2019 (Analisis RCA dan EPD)}

Tabel 2 menunjukkan bahwa indeks RCA komoditas biji pala Indonesia ke tujuh negara Uni Eropa menunjukkan nilai yang berfluktuatif. Komoditas biji pala Indonesia di masing-masing negara telah memiliki keunggulan komparatif selama periode 2012-2019. Hal ini ditunjukkan oleh nilai indeks RCA yang lebih dari satu. Nilai yang selalu di atas satu mengindikasikan bahwa komoditas biji pala Indonesia banyak diminati oleh ketujuh negara Uni Eropa. Indeks RCA tertinggi diraih oleh Belgia, sedangkan yang terendah adalah Inggris.

Tabel 2. Hasil penghitungan RCA dan EPD biji pala Indonesia di tujuh negara Uni Eropa periode 2012-2019

\begin{tabular}{cccccccccc}
\hline \multirow{2}{*}{ Negara Tujuan } & \multicolumn{7}{c}{ RCA } & \multirow{2}{*}{ EPD } \\
\cline { 2 - 9 } & 2012 & 2013 & 2014 & 2015 & 2016 & 2017 & 2018 & 2019 & \\
\hline Belanda & 98,57 & 81,81 & 78,36 & 81,46 & 95,53 & 78,61 & 60,18 & 85,25 & Retreat \\
Belgia & 318,48 & 204,76 & 244,92 & 232,30 & 213,19 & 197,06 & 193,82 & 223,33 & Retreat \\
Inggris & 52,64 & 29,06 & 43,11 & 54,99 & 19,14 & 48,49 & 80,62 & 74,15 & Falling Star \\
Itali & 157,53 & 166,26 & 141,33 & 155,40 & 173,65 & 169,34 & 186,28 & 188,40 & Retreat \\
Jerman & 159,17 & 147,48 & 180,19 & 162,45 & 166,70 & 191,85 & 206,19 & 242,91 & Falling Star \\
Prancis & 180,19 & 198,74 & 179,27 & 186,34 & 117,14 & 170,47 & 148,35 & 163,33 & Retreat \\
Spanyol & 42,94 & 87,92 & 69,83 & 94,78 & 85,48 & 83,81 & 68,30 & 96,12 & Falling Star \\
\hline
\end{tabular}

Sumber: UN Comtrade (diolah)

Meski memiliki keunggulan komparatif yang baik, hasil penghitungan EPD menunjukkan posisi daya saing yang kurang baik. Posisi pasar komoditas biji pala Indonesia di negara Belanda, Belgia, Italia, dan Prancis berada pada posisi retreat. Posisi ini bukanlah posisi yang diharapkan karena baik pangsa total ekspor Indonesia maupun pangsa ekspor biji pala Indonesia tidak lagi mengalami pertumbuhan atau bisa dibilang stagnan di keempat negara tersebut. Sedangkan untuk negara Inggris, Jerman, dan Spanyol, keunggulan kompetitif berada pada posisi falling star. Posisi ini lebih baik dibandingkan dengan posisi retreat karena meskipun pangsa total ekspor Indonesia tidak dinamis lagi, pangsa ekspor biji pala Indonesia masih dalam keadaan yang dinamis (meningkat).

Faktor-Faktor yang Mempengaruhi Volume Ekspor Pala Indonesia di Tujuh Negara Uni Eropa Periode 20122019

\section{Pemilihan Model Terbaik}

Hasil pada Tabel 3 menunjukkan bahwa baik uji Chow maupun uji Hausman memberikan kesimpulan yang serupa, dimana model terbaik yang terpilih untuk mengestimasi model regresi data panel adalah fixed effect model (FEM). Karena model yang terpilih adalah FEM, selanjutnya dilakukan pengujian pada struktur varians-kovarians residual. 
Tabel 3. Hasil uji pemilihan model terbaik (uji Chow dan uji Hausman)

\begin{tabular}{ccccccc}
\hline Uji & $\boldsymbol{H}_{\mathbf{0}}$ & $\boldsymbol{H}_{\mathbf{1}}$ & Statistik Uji & $p$-value & Keputusan & Kesimpulan \\
\hline Chow & CEM & FEM & 130,5239 & 0,0000 & Tolak $H_{0}$ & FEM \\
Hausman & REM & FEM & 23,3686 & 0,0003 & Tolak $H_{0}$ & FEM \\
\hline
\end{tabular}

Pengujian Struktur Varians-Kovarians

Berdasarkan Tabel 4, statistik uji LM menunjukkan nilai yang lebih besar dibandingkan nilai chi-square tabelnya sehingga keputusan yang diambil adalah tolak $H_{0}$. Pada taraf uji $5 \%$ terdapat cukup bukti bahwa struktur varians-kovarians residual bersifat heteroskedastis. Pengujian dilanjutkan dengan uji $\lambda_{L M}$ untuk menguji keberadaan cross-sectional correlation. Hasil uji pada Tabel 3 menunjukkan bahwa nilai statistik uji lebih besar disbandingkan dengan chi-square tabel sehingga keputusan yang diambil adalah tolak $H_{0}$. Pada taraf uji 5\% terdapat cukup bukti bahwa terdapat cross-sectional correlation pada struktur varians-kovarians residual. Berdasarkan hasil kedua uji di atas, metode estimasi yang tepat untuk digunakan adalah feasible generalized least square (FGLS) dengan pendekatan cross-section seemingly unrelated regression (SUR). Karena metode estimasi FGLS-SUR telah mengakomodasi heteroskedastisitas dan autokorelasi (Greene, 2012), asumsi klasik yang perlu terpenuhi adalah normalitas dan non multikolinearitas.

Tabel 4. Hasil uji lagrange multiplier dan uji $\lambda_{L M}$

\begin{tabular}{ccccccc}
\hline Uji & $\boldsymbol{H}_{\mathbf{0}}$ & $\boldsymbol{H}_{\mathbf{1}}$ & Statistik Uji & Chi-square & Keputusan & Kesimpulan \\
\hline LM & Homoskedastis & Heteroskedastis & 15,45 & 12,59 & Tolak $H_{0}$ & Heteroskedastis \\
$\boldsymbol{\lambda}_{\mathbf{L M}}$ & $\begin{array}{c}\text { Tidak terdapat } \\
\text { cross-sectional } \\
\text { correlation }\end{array}$ & $\begin{array}{c}\text { Terdapat cross- } \\
\text { sectional } \\
\text { correlation }\end{array}$ & 73,05 & 32,67 & Tolak $H_{0}$ & $\begin{array}{c}\text { Terdapat cross- } \\
\text { sectional correlation }\end{array}$ \\
& & & & & \\
\hline
\end{tabular}

Pengujian Asumsi Normalitas dan Non Multikolinearitas

Berdasarkan Tabel 5, statistik uji Jarque-Bera bernilai 1,202972 dengan p-value sebesar 0,547997. Karena nilai $p$-value lebih besar dari $\alpha=0,05$, keputusan yang diambil adalah gagal tolak $H_{0}$. Pada tingkat kepercayaan 95\% dapat disimpulkan bahwa residual berdistribusi normal sehingga asumsi normalitas telah terpenuhi.

Tabel 5. Hasil uji normalitas menggunakan Jarque-Bera

\begin{tabular}{ccc}
\hline & Statistik Uji & Probabilitas \\
\hline Jarque-Bera & 1,202972 & 0,547997 \\
\hline
\end{tabular}

Kemudian untuk mendeteksi gejala multikolinearitas dilakukan penghitungan variance inflation factors (VIF). Nilai VIF lebih dari 10 mengindikasikan adanya gejala multikolinearitas. Tabel 6 menunjukkan nilai VIF dari masing-masing variabel independen tidak melebihi 10. Oleh karena itu dapat disimpulkan bahwa tidak terdapat gejala multikolinearitas sehingga asumsi non multikolinearitas telah terpenuhi.

Tabel 6. Hasil penghitungan VIF

\begin{tabular}{cc}
\hline Variabel Independen & VIF \\
\hline DHC & 1,657693 \\
PDB & 1,160277 \\
Harga & 1,471822 \\
Produksi & 1,069363 \\
lnRCA & 1,14868 \\
\hline
\end{tabular}

Pengujian Keberartian Model

Berdasarkan Tabel 7, nilai adjusted R-square sebesar 0,99945. Artinya sebesar 99,945 persen keragaman atau variasi dari volume ekspor biji pala Indonesia ke tujuh negara Uni Eropa mampu dijelaskan oleh variabel dummy regulasi health certificate, PDB riil per kapita, harga riil, laju produksi biji pala Indonesia, dan daya saing biji pala Indonesia. Sedangkan sisanya sebesar 0,055 persen dijelaskan oleh variabel lain yang berada di luar model. Hasil tersebut menunjukkan bahwa model yang digunakan telah fit. 
Tabel 7. Hasil pengujian keberartian model

\begin{tabular}{|c|c|c|c|c|c|}
\hline Variabel & Koefisien & Std. Error & t-stat & t-tabel & Prob. \\
\hline Konstanta & 15,6700 & 0,235748 & 66,46925 & 2,01537 & 0,0000 \\
\hline DHC & 0,0510 & 0,003998 & 12,75865 & 2,01537 & 0,0000 \\
\hline PDB & $-0,1626$ & 0,005398 & $-30,11342$ & 1,68023 & 0,0000 \\
\hline Harga & $-0,0564$ & 0,001509 & $-37,38284$ & $-1,68023$ & 0,0000 \\
\hline Produksi & 0,0020 & 0,000106 & 19,09534 & 1,68023 & 0,0000 \\
\hline $\operatorname{lnRCA}$ & 0,9285 & 0,003762 & 246,84 & 1,68023 & 0,0000 \\
\hline \multicolumn{6}{|c|}{ Ringkasan Statistik } \\
\hline$R$-square & 0,99956 & & F-stat & 9088,84 & \\
\hline Adjusted $R$-square & 0,99945 & & Probability & 0,00000 & \\
\hline \multicolumn{6}{|c|}{ Fixed Effect $($ Cross Section $)$} \\
\hline Belanda & 3,295 & & & & \\
\hline Belgia & 0,091 & & & & \\
\hline Inggris & $-0,439$ & & & & \\
\hline Italia & $-1,129$ & & & & \\
\hline Jerman & 1,178 & & & & \\
\hline Prancis & $-0,887$ & & & & \\
\hline Spanyol & $-2,109$ & & & & \\
\hline
\end{tabular}

Hasil pengujian simultan menggunakan uji $\mathrm{F}$ menunjukkan nilai statistik uji sebesar 9088,84 dengan $p$ value sebesar 0,0000. Karena $p$-value lebih kecil dibandingkan $\alpha=0,05$, keputusan yang diambil adalah tolak $H_{0}$. Pada taraf uji 5\% menunjukkan terdapat cukup bukti bahwa minimal terdapat satu variabel independen yang berpengaruh terhadap volume ekspor biji pala Indonesia di tujuh negara Uni Eropa periode 2012-2019.

Kemudian, hasil uji parsial menggunakan uji t menunjukkan bahwa nilai mutlak t-statistik untuk variabel regulasi health certificate yaitu 12,76 yang bernilai lebih besar daripada $t_{(0,025 ; 44)}$ yaitu 2,0154. Oleh karena itu, pada tingkat signifikansi 5\% terdapat cukup bukti bahwa variabel regulasi health certificate berpengaruh signifikan terhadap volume ekspor biji pala Indonesia. Kemudian untuk variabel PDB riil per kapita negara tujuan memiliki nilai t-statistik sebesar -30,11 yang lebih kecil dibandingkan dengan $t_{(0,05 ; 44)}$ yaitu 1,6802 sehingga keputusan gagal tolak hipotesis nol dan dapat disimpulkan bahwa pada taraf signifikansi 5\%, belum terdapat cukup bukti yang menunjukkan variabel PDB riil per kapita berpengaruh signifikan positif terhadap volume ekspor biji pala Indonesia. Lalu variabel harga riil ekspor biji pala memiliki nilai t-statistik sebesar 37,38 dan nilainya lebih kecil dibandingkan dengan $-t_{(0,05 ; 44)}$ yaitu $-1,6802$. Oleh karena itu, dapat disimpulkan bahwa pada taraf signifikansi 5\% terdapat cukup bukti bahwa harga riil ekspor biji pala berpengaruh signifikan negatif terhadap volume ekspor biji pala Indonesia. Selain itu diketahui juga bahwa tstatistik dari laju produksi dan indeks daya saing (RCA) bernilai lebih besar dibandingkan dengan $t_{(0,05 ; 44)}$ yaitu 1,6802 sehingga hipotesis nol ditolak dan dapat disimpulkan bahwa kedua variabel tersebut berpengaruh signifikan positif terhdapa volume ekspor biji pala Indonesia.

Tabel 7 menunjukan bahwa efek individu yang dihasilkan menunjukkan bahwa Belanda memiliki efek terbesar. Ini artinya ketika semua variabel independen dalam model dianggap konstan, ekspor biji pala Indonesia ke Belanda memiliki volume yang paling besar dibandingkan keenam negara Uni Eropa lainnya Sedangkan efek terkecil dimiliki oleh Spanyol. Hal ini menunjukkan bahwa ketika semua variabel independen dalam model dianggap konstan, ekspor biji pala Indonesia ke Spanyol memiliki volume yang paling kecil dibandingkan keenam negara Uni Eropa lainnya.

Interpretasi Model Regresi Terpilih

Berikut adalah persamaan yang terbentuk pada penelitian ini.

ln $\widehat{E k s p}$ or $_{i t}=\left(15,67+\hat{\mu}_{i}\right)^{*}+0,051005 D H C_{t}^{*}-0,162555 P D B_{i t}-0,056424$ Harga $_{i t}^{*}+$ 0,002029 Produksi $_{t}^{*}+0,928497 \ln R C A_{i t}^{*}$

Keterangan:

* signifikan pada taraf signifikansi 5\%. 
Pada Persamaan 7 diperoleh nilai koefisien dummy regulasi health certificate sebesar 0,051. Artinya ketika regulasi health certificate diberlakukan, volume ekspor biji pala Indonesia lebih tinggi sebesar 5,1 persen dibandingkan dengan sebelum diberlakukannya regulasi dengan asumsi variabel bebas lainnya konstan. Hal ini sejalan dengan harapan awal Badan Ketahanan Pangan (2018), yaitu penerbitan health certificate sebagai respon dari diberlakukannya regulasi health certificate ini mampu memberikan jaminan keamanan biji pala dari kontaminasi aflatoksin sehingga resiko penolakkan oleh Uni Eropa dapat diperkecil. Selain itu, hal ini dapat meningkatkan kepercayaan diri perusahaan eksportir dalam melakukan ekspor sehingga volume ekspor dari sisi penawaran dapat meningkat.

Harga riil ekspor memiliki nilai koefisien sebesar -0,056424. Hal ini menunjukkan bahwa setiap kenaikan harga riil ekspor sebesar satu dolar, akan menurunkan volume ekspor biji pala Indonesia sebesar 5,6424 persen dengan asumsi ceteris paribus. Hasil ini sesuai dengan teori permintaan, bahwa kenaikan harga suatu barang dan/atau jasa akan menyebabkan penurunan permintaan akan barang dan/atau jasa tersebut. Penelitian yang dilakukan oleh Atici (2013) mengenai ekspor buah tin dan kemiri menunjukkan hasil serupa, bahwa harga berpengaruh negatif terhadap volume ekspor.

Laju produksi pala Indonesia memiliki nilai koefisien sebesar 0,002029. Hal ini menunjukkan bahwa setiap kenaikan laju produksi pala Indonesia sebesar satu persen, akan meningkatkan volume ekspor biji pala Indonesia sebesar 0,002029 persen dengan asumsi ceteris paribus. Hasil ini sejalan dengan teori yang dikemukakan Sukirno (2004) bahwa produksi yang melimpah akan menyebabkan excess supply sehingga ekspor dilakukan untuk memperluas pasar. Penelitian yang dilakukan oleh Hakiki dan Asnawi (2019) turut mendukung hasil ini, bahwa semakin tinggi produksi, akan meningkatkan volume ekspor dari sisi penawaran.

Indeks daya saing (RCA) memiliki nilai koefisien sebesar 0,928497. Hal ini menunjukkan bahwa setiap kenaikan indeks daya saing (RCA) sebesar satu persen, akan meningkatkan volume ekspor biji pala Indonesia sebesar 0,928497 persen dengan asumsi ceteris paribus. Hal ini sesuai dengan hipotesis penelitian serta penelitian yang dilakukan oleh Safitri dan Kartiasih (2019). Indeks daya saing (RCA) dapat digunakan untuk melihat tingkatan daya saing suatu komoditas di pasar negara tujuan. Joewono dalam Goestjahjanti (2016) menjelaskan bahwa daya saing dapat mempermudah akses pasar sehingga peningkatan daya saing akan memberikan dampak positif bagi ekspor suatu negara.

\section{KESIMPULAN}

Berdasarkan hasil dan pembahasan dengan analisis deskriptif dengan metode grafik serta metode RCA dan EPD maka dapat disimpulkan bahwa volume ekspor biji pala Indonesia ke tujuh negara Uni Eropa periode 2012-2019 cukup berfluktuasi dengan volume ekspor tertinggi adalah ke negara Belanda, dan yang terendah adalah ke negara Inggris. Komoditas biji pala Indonesia telah memiliki keunggulan komparatif yang ditunjukan oleh nilai RCA yang lebih dari 1 dengan posisi pasar komoditas biji pala Indonesia berada pada posisi falling star untuk negara Inggris, Jerman, dan Spanyol. Sedangkan untuk negara Belanda, Belgia, Italia, dan Prancis berada pada posisi retreat. Hasil analisis inferensia dengan metode regresi data panel menunjukan bahwa dummy regulasi health certificate, laju produksi pala Indonesia, dan indeks daya saing (RCA) memiliki pengaruh positif signifikan terhadap volume ekspor biji pala Indonesia. Sedangkan harga riil ekspor memiliki pengaruh negatif signifikan terhadap volume ekspor biji pala Indonesia. Efek individu yang terbesar adalah negara Belanda, dan yang terkecil adalah negara Spanyol.

\section{DAFTAR PUSTAKA}

Atici, C. (2013). Food Safety Regulations and Export Responses of Developing Countries: The Case of Turkey's Fig and Hazelnut Exports. FAO Commodity and Trade Policy Research Working Paper No. 39.

Badan Ketahanan Pangan. (2018). BKP Kementan dorong ekspor pala melalui penerbitan Health Certificate (HC). Retrieved from Berita BKP: http://bkp.pertanian.go.id/blog/post/bkp-kementan-dorong-eksporpala-melalui-penerbitan-health-certificate-hc.

Dewi, N. S. (2016). Faktor Meningkatnya Ekspor Buah Pala Indonesia-Uni Eropa. JOM FISIP, 3(2), 01-13.

DG(SANTE). (2016). Final Report of an Audit Carried Out in Indonesia from 07 March 2016 to 17 March 2016 in Order to Assess the Controls of Aflatoxin Contamination in Nutmeg Intended for Export to the European Union. DG(SANTE). Brussels.

Direktorat Jenderal Perkebunan. (2019). Statistik Perkebunan Indonesia: Pala 2018-2020. Jakarta: Sekretariat Direktorat Jenderal Perkebunan.

Estherhuizen, D. (2006). Measuring and Analyzing Competitiveness in the Agribusiness Sector: Methodological and Analytical Framework. University of Pretoria, 107(4), 823-824. 
Goestjahjanti, F. S. (2016). Pengaruh Faktor Inti Nilai Tukar Dan Daya Saing Terhadap Term of Trade Serta Dampaknya Kepada Daya Beli Masyarakat Indonesia. Jurnal Bisnis dan Manajemen (Journal of Business and Management), 16(2), 35-48.

Greene, W. H. (2012). Econometric Analysis Seventh Edition. Essex: Pearson Education Limited.

Hafif, B. (2021). The Strategy to Maintain Indonesia as a Main Nutmeg Producer in the World. Jurnal Penelitian dan Pengembangan Pertanian, 40(1), 58-70.

Hakiki, S. I., \& Asnawi, A. (2019). Pengaruh Luas Lahan, Produksi, Harga Kakao Internasional terhadap Ekspor Kakao Indonesia. Jurnal Ekonomi Pertanian Unimal, 2(1), 48-64.

INAagrimap. (2018). Pala. Retrieved from INAagrimap: https://inaagrimap.litbang.pertanian.go.id/index.php/sentra-produksi/tanaman-perkebunan/pala

Kementerian Pertanian. (2016). Outlook Pala 2016. Sekretariat Jenderal Kementerian Pertanian, Jakarta.

Khoironi, F. E., \& Saskara, I. A. N. (2017). Analisis pengaruh kurs dollar, inflasi, dan produksi terhadap ekspor ikan hias di provinsi bali. E Jurnal EP Universitas Udayana, 6(3).

Lawalata, M. (2019). Analisis Saluran Pemasaran Pala Banda (Myristica fragrans Houtt) di Kecamatan Banda Neira Kabupaten Maluku Tengah. Jurnal Ilmu Pertanian AGRIC, 31(1), 01-14.

Laursen, K. (2015). Revealed Comparative Advantage and the Alternatives as Measure of International Specialization. Eurasian business review, 5(1), 99-115.

Mankiw, G. N. (2003). Pengantar Ekonomi Edisi Kedua Jilid 2. Jakarta: Penerbit Erlangga.

Maulana, A., \& Kartiasih, F. (2017). Analisis ekspor kakao olahan Indonesia ke sembilan negara tujuan tahun 2000-2014. Jurnal Ekonomi dan Pembangunan Indonesia, 17(2), 103-117.

Nabi, I., \& Luthria, M. (Eds.). (2002). Building Competitive Firms: Incentives and Capabilities. World Bank Publications.

Pindyck, R. S., \& Rubinfield, D. L. (2013). Microeconomics 8th Edition. New Jersey: Pearson Education, Inc.

Rosman, R. (2020). Permasalahan Pengembangan dan Inovasi Teknologi Budidaya Tanaman Pala Berbasis Ekologi (The Problem of The Development and Technology Inovation of Ecology-Based Nutmeg Cultivation). Perspektif, 19(1), 53-62.

Safitri, V. R., \& Kartiasih, F. (2019). Daya Saing dan Faktor-Faktor yang Mempengaruhi Ekspor Nanas Indonesia. Jurnal Hortikultura Indonesia, 10(1), 63-73.

Soeharjoto. (2016). Pengaruh Penanaman Modal Asing dan Tingkat Daya Saing terhadap Ekspor Industri Manufaktur Indonesia. Media Ekonomi, 24(2), 161-174.

Sofjan, M. (2017). The Effect of Liberalization on Export-import in Indonesia. International Journal of Economics and Financial Issues, 7(2), 672-676.

Sukirno, S. (2004). Makro Ekonomi Teori Pengantar Edisi Ketiga. Raja Grafindo Persada, Jakarta.

Wiranthi, P. E., \& Mubarok, F. (2017). Competitiveness and the Factors Affecting Export of Indonesia Canned Pineapple in the World and the Destination Countries. KnE Life Science, 339-352. 